\title{
Determining the Motor Skills Development of Mentally Retarded Children through the Contribution of Visual Arts
}

\author{
Gonca Erim ${ }^{1, *}$, Müge Caferoğlü \\ ${ }^{1}$ Department of Art Education, Faculty of Education, Uludağ University, Turkey \\ ${ }^{2}$ Faculty of Fine Arts, Uludağ University, Turkey
}

Copyright $\bigcirc 2017$ by authors, all rights reserved. Authors agree that this article remains permanently open access under the terms of the Creative Commons Attribution License 4.0 International License

\begin{abstract}
Visual arts education is a process that helps the reflection of inner worlds, socialization via group works and healthier motor skills development of normally developing or handicapped children like the mentally retarded. This study aims to determine the influence of visual art studies on the motor skills development of primary school first grade level trainable mentally retarded children and the difficulties faced related to this process. The target population of this study consists of special education teachers working for private special education institutions and the sample of this study consists of eighty-five special education teachers working for fifteen special education institutions within the province of Bursa. In this screening survey model study, questionnaires have been used as a data collection technique. The results have been interpreted by analyzing in table forms. According to the findings obtained in the research, most of the participating teachers think that visual art education plays an important role in the development of mentally retarded children and visual arts classes are beneficial to developing motor skills and improves hand-eye coordination. However, it has been determined that some applications, which were included in the visual arts education curriculum, have not been practised. In accordance with the findings obtained in the research, it has been suggested that the applications containing fine motor skills development movements should take place more in art education programs, and that special education institutions should have an art educator and art studios in order to improve motor skills level of mentally handicapped children.
\end{abstract}

Keywords Fine Arts Education, Visual Arts Education, Mentally Retarded Children, Special Education

\section{Introduction}

Education is a process that raises individuals in accordance with specific goals. This process lasts both inside and outside of the school during our lifetime. Throughout the history each scientists have emphasized different aspects of education. "Education is a planned activity which helps to result in specific developments according to determined aims on human behaviors. It is a matter for mentally handicapped individuals to experience same stages as for all individuals. However, it is a known fact that individuals with mental retardation experience more different processes than the others." [11]

The physiological, social and cultural limitations of children influence their educational capacity and their response to education. Generally responses below the expectations are at the point where special education begins. As in every field, in special education, too, terminology and definitions are in a constant change with the development of social and cultural structure and technological improvements. [5] Educating and helping the handicapped children to become productive is significant in terms of both the individuals and the society. Mentally retarded children have the basic needs as the normal children have. However, they differ because of the retardation on their physical, mental and social development. They have the rights to be educated, to have fun, to benefit from opportunities and to improve their abilities as every child does. Regardless of the degree of the disability, every individual has a right for education.

Art activities for education of both normal and handicapped children have become more important gradually. The reason is that art education facilitates the learning process in a positive environment by influencing all developmental areas of children. Therefore, art education must be emphasized further for children with special education needs through serious and devoted studies.

Visual arts education is a psychologically relaxing process which helps individuals to express themselves, to have an enjoyable time and to gain different hand craft skills. By 
enriching children's personality, this educational process facilitates behavioral development via social and aesthetic attainments. Visual arts lesson plays an important role for mentally retarded children as it allows them to express their different feelings. Individuals who improve their behavioral language become more tolerant and understanding of themselves and other individuals, succeed in becoming more productive and skilled individuals and have a better opportunity at fulfilling their potential. They can adapt to their own environment positively and enjoy their lives. Accordingly, it is a point of agreement among educators that art education plays an essential role in the process of self-realization, creativity and personal development.

This research consists of findings that have been obtained from the master's degree thesis study prepared by Research Assistant Müge (Aksu) Caferoğlu and consulted by Assistant Professor Dr. Gonca Erim, "Contribution of Visual Arts Education on Motor Skills Development of Mentally Retarded Children", related to the opinions of special education teachers in terms of the influence of art studies on motor skills development of mentally retarded children.

Based on the necessity of visual art education for all disabled or non-disabled individuals, this study has been carried out to emphasize the importance of visual arts education on special education. In this research, the techniques of visual arts lesson and studies of the program have been analyzed in accordance with the opinions of special education teachers.

\subsection{General Overview of Special Education around the World and in Our Country}

Special education indicates "an education given by considering the needs of teenagers or disabled children who are not found suitable to be educated at any stages of normal education system".[2] Special education is generally preferred when the educational needs of the individual cannot be fulfilled by normal classes or schools related to their retardation type and degree. Special education can be given at rehabilitation centers apart from schools as well as special education classes of normal schools where handicapped children are educated alongside with students of at the same age without disabilities. Special education field has been supported by both governmental and private special education institutions.

General overviews show that each country determines its own aims in accordance with its own needs and tries to develop strategies to achieve its goals. In many developed countries, most of the children with mental retardation are educated in special classes in their neighborhood. In these countries mentally retarded children have the opportunity to be in the same class with their peers for some non-academic subjects. Many studies have proved that mentally retarded children in inclusive classes are more successful in terms of academic improvement and develop better interpersonal skills. [1]
In many non-European countries new practices in special education field have been used recently. Special education teachers and experts have started to provide on-the-job training activities, consultancy services and support programs for the families by sharing their knowledge and experiences with the administrative and academic staff of normal educational schools in their regions.

According to the analysis of our country, Turkey, special education services for children with a lesser degree of mental retardation have been carried out mostly in special classrooms, while services for "moderate" mentally retarded individuals have been carried in private day-time schools. Apart from private institutions, governmental schools or centers, universities and voluntary associations have been providing those services as well. Accordingly, which institution each child will be sent to and which program each child will attend are determined by the experts. [3]

It should be never forgotten that mentally retarded individuals are in need of education as other healthy individuals in the society, and when the opportunity is provided they can improve themselves to become socially beneficial individuals. It is the duty of the society to help these individuals to benefit from an education that is suitable for their disabilities during the reintegration process.

\subsection{Art Education for Mentally Retarded Children}

Art education can be defined as a visual thinking education process. Language is the basic need to express what we think. It is a clear example of this need that centuries ago drawings were used by cave dwellers as well as a speaking language and supporting it with colors and other things as tools of communication. Individuals have always been in the need for a second language to express their feelings and opinions. The main purpose of fine arts education in our time is to construct a language via artistic ways such as drawings, color, etc. [4] Art is an expression tool which exists in our Daily life, and with its communicational functions, it has made a huge contribution to the improvement of the societies.

Visual art education is a process which helps children, normally developed and mentally retarded alike, to socialize via group works, to express their own inner worlds and to develop healthy motor skills. Throughout human history art has played an important role at any developmental stage and still carries this importance. Focusing on the first cave dwellers' lifestyle, it can be observed that mankind tried to express itself via colors and various symbols before using verbal communication. Especially mentally retarded children with difficulties in their daily life social skills can use visual arts education as a tool to express their inner worlds.

Educating children in special classrooms can be problematic in many aspects. Visual arts teachers may not be ready to educate children with special needs or special class teachers might be responsible for the instruction. Art teachers working in special education institutions must be 
experienced in this field. Art teachers need to determine their weaknesses related to the field, construct a perspective for recognition, develop teaching methods and try to teach these to mentally retarded children. [10] When art teachers are more qualified and experienced on the field, their education will be more effective for mentally retarded children.

Art materials result in beneficial outcomes for mentally retarded children in terms of coordinated use of their hands and eyes simultaneously. Different materials and methods affect the developmental processes of children and increase their interest for art lessons. Since techniques and methods taught by working with different materials help children link their physical and personal features, children find opportunities to express themselves in a better way. Art teachers need to be aware of all the materials. Education via artistic activities may be more beneficial and attractive for developmental processes of children.

The activities may make use of paints, paintbrushes, paper, cardboard, clay and even recycled materials. The paintings created by children with crayons and coloring pencils will improve once the children learn how to hold a brush and paint with watercolor. The activities should consist of the coloring of delineated shapes without any free style coloring and should include instructions. Making appropriate use of the inductive method renders these activities both more efficient and permanent.

Benefits of art education in terms of developmental fields can be listed as:

a) Physical development; helps to improve fine and gross motor coordination and supports hand - eye coordination development. "Education activities need to be organized in order to improve fine and gross motor skills of children and this process needs to be supported by drawing, painting and simple three dimensional works in a free atmosphere by using materials like primarily blunt pencils, crayons, fine and coarse brushes, etc.". [6]

b) Cognitive development; generally helps to learn notions, improve mathematical and problem solving skills and develop aesthetical and artistic skills.[8] "Art education is closely related to mental functioning, ability and creativity development processes of children. Cognitive process, based on the senses and sensations, is in need of positive stimulus to improve and direct the functioning of sensations. As the development on physical competence depends on the process and the interaction turns into behaviors via stimuli, the mental development needs effective stimuli, too." [6]

c) Language development; the receiver and the source help to support language development and to name the art related concepts.

d) Art education on social development field; helps to improve and support skills such as sharing, collaboration, cooperatively planning, verbal communication and group adaptation.[8] "A completed education occurs only when individuals reach a healthy and improved personality, get qualified with creative power and be able to keep up with the changing world conditions.". .[6]

e) As for the emotional development field, art education helps individuals to be aware of their emotions and express themselves and to develop self-esteem and reliability.

Visual arts education is an education process which helps individuals to develop self-expression, enriches their personalities and provides behavioral improvement via social and aesthetic acquisitions. Visual arts education is vital for the self-expressions of mentally retarded children.

\subsection{Motor Development of Mentally Retarded Children}

In the field of human development terminology the word 'motor' is used to refer 'action'. The developmental process begins physically while the individuals are still in the womb and continues rapidly after birth. While some of the actions in the developmental process turns into reflexes and lasts the entire lifetime, some actions turns into motor skills with the help of using organs consciously. However, standing on one foot or cutting paper are the actions performed by using the organs consciously and considered as 'psychomotor development'. [9] Motor development process is vital for the development of children and lasts their entire lifetime.

Mentally retarded children have some incompetency with their motor developmental process as with other developmental processes. Motor development improves with physical development and growth. Physical growth and development of mentally retarded children are slower compared to their peers depending on different factors and affects their fine and gross motor hand-eye coordination. [12] Since the first days of their lives, mentally retarded children experience retardations on their motor development processes as a result of their weak muscles.

Being aware of children's motor development levels is important in terms of their education. Abilities and skills of children are important factors on acquiring skills during the motor development process. Perceptual motor skills and readiness help to acquire and develop skills concepts. As in other developmental periods, age determination in accordance with the periods is also universal in motor development. Each individual has her own way of thinking, moving, feeling, speaking and understanding.

Compared to children of their age, mentally retarded children are less skilled in some areas "especially like balance, action and hand crafts. Researches prove that compared to children of their age, mentally retarded children experience hearing and vision disorders more often. All these health problems may occur related to genetic or environmental factors". [7] Activities related to motor development make huge contribution to not only the physical development processes of children, but also the social and emotional development processes. All the art activities are as vital as other academic subjects. With the help of 
psychomotor activities, children identify their own body and realize their abilities and limitedness. While the activities and programs are prepared by the experts, all the developmental features and individual differences of children should be considered and exclusive programs should be designed.

\section{Aim and Importance of the Study}

This study aims to find out the effects of visual art education of primary level first grader trainable mentally retarded children on motor skills development and the difficulties that are faced during the process "The term 'trainable' in this context means that the children in this group could acquire basic academic skills such as reading, writing and maths. The children show a close-to-normal development in their physical features and motor skills. However, their interest and attention span is short and limited. They are able to have social interactions but the difficulty they have in following social norms might create problems at home and in school. There are inadequacies in their understanding of oral guidance, concepts and stillness." [2] The cognitive development of mentally handicapped individuals in this group is similar to their peers; however, they follow the same developmental stages at a slower pace. The pace varies with the individual's handicap. In line with this objective, this research contains the views and suggestions of special education teachers related to the skills needed to be acquired and difficulties faced while practicing activities in visual arts lessons.

This study is important in terms of determining the effect of visual arts education activities prepared for trainable mentally retarded children on social behavior acquisition and motor development processes. This study is considered to be important in terms of determining the activities to be practiced on hand craft development of mentally retarded children, making suggestions to special education teachers in this field and emphasizing the importance of visual arts education in the special education process.

\section{Methods}

In this study, which aims to analyze the effects of visual art education of primary level first grader trainable mentally retarded children on motor skills development the screening survey model has been used. For the screening process, questionnaires have been prepared and special education teachers' opinions have been recorded. Data collected by the literature review have been analyzed and interpreted.

In this study, a 33-question questionnaire has been administered to 85 special education teachers working in 13 private and 2 public special education institutions located in the 3 central neighborhoods of Bursa, namely Nilüfer,
Osmangazi and Yildırım, in order to evaluate the impact of visual arts education on the motor skills development of trainable mentally retarded students. The questionnaire has been sent to school principals by the Bursa Provincial Directorate of National Education with a formal permission letter.

In order to determine the validity of the questionnaire's content and given that the reviewed literature did not yield a sample, the questionnaire has been reviewed by the thesis advisor and expert educators before its administration. The questionnaire has been revised with this input to ensure that the questions are clear and understandable and yield the necessary information.

The form starts with personal questions for the respondents, which allow for the collection of data on gender, education status, experience and specialty. Questions 1 through 6 reflect the attitude of and physical conditions in the educational institution regarding visual arts classes. Questions 7 through 14 reflect the teachers' views regarding visual arts classes. Questions 15 through 20 aim to determine the status of mentally handicapped students in the visual arts class, while questions 21 through 31 focus on the teachers' methods for the class. The $32^{\text {nd }}$ question aims to determine the impact of visual arts activities on the motor skills development of the mentally handicapped students, as well as the activities that are deemed the most and the least effective by the teachers. The last and $33^{\text {rd }}$ question aims to determine the difficulties faced by children during the activities, as well as the teachers' views on the most and least difficult activities.

This article aims to assess the impact of visual arts activities on the motor skills development of mentally handicapped children. In this regard, the analysis, graphs and interpretation of the $32^{\text {nd }}$ question, out of 33 questions under 14 headings, sets the framework for the article. As mentioned before, Kulaksızoğlu and Günaydın carried out research on the impact of visual arts education on the physical, cognitive, social and linguistic development of mentally handicapped children. This previous research has been used to determine the techniques of the $32^{\text {nd }}$ question which includes 14 items. In the next stage, the data obtained by the questionnaire have been analyzed and summarized in frequency and percentage with tables and interpretation.

\section{Findings}

In the study, in order to determine the teachers opinions related to effects of the practices used in visual arts lessons on mentally retarded children, frequency (f) and percentage (\%) distributions have been listed in Table 1. Apart from this, the findings related to each resolution as (\%) distribution and the interpretations of these findings have been provided. 
Table 1. Degree of influence; artistic practices on motor development of mentally retarded children $(\mathrm{n}=85)$

\begin{tabular}{|c|c|c|c|c|c|c|c|c|c|}
\hline \multicolumn{2}{|r|}{ Types of Artwork } & \multicolumn{2}{|c|}{ High } & \multicolumn{2}{|c|}{ Middle } & \multicolumn{2}{|c|}{ Low } & \multicolumn{2}{|c|}{ None } \\
\hline No & & $\mathrm{f}$ & $\%$ & $\mathrm{f}$ & $\%$ & $\mathrm{f}$ & $\%$ & $\mathrm{~F}$ & $\%$ \\
\hline 1 & Paper works & 50 & 59 & 35 & 41 & - & - & - & - \\
\hline 2 & Drawings & 67 & 79 & 17 & 20 & 1 & 1 & - & - \\
\hline 3 & Colored large size works & 49 & 58 & 33 & 39 & 3 & 3 & - & - \\
\hline 4 & Colored small size works & 42 & 49 & 40 & 47 & 3 & 4 & - & - \\
\hline 5 & Print works & 38 & 45 & 39 & 46 & 7 & 9 & - & - \\
\hline 6 & Two dimensional works & 37 & 44 & 41 & 48 & 7 & 8 & - & - \\
\hline 7 & Three dimensional works & 42 & 49 & 31 & 37 & 11 & 13 & 1 & 1 \\
\hline 8 & Waste material works & 44 & 52 & 32 & 38 & 9 & 10 & - & - \\
\hline 9 & Stained glass works & 18 & 21 & 33 & 39 & 24 & 28 & 10 & 12 \\
\hline 10 & Free works & 50 & 59 & 28 & 33 & 7 & 8 & - & - \\
\hline 11 & Hand craft works & 52 & 61 & 27 & 32 & 4 & 5 & 2 & 2 \\
\hline 12 & Collage works & 39 & 46 & 29 & 34 & 11 & 13 & 6 & 7 \\
\hline 13 & Stencil works & 30 & 35 & 35 & 41 & 12 & 14 & 8 & 10 \\
\hline 14 & Other .............. & - & - & - & - & - & - & - & - \\
\hline
\end{tabular}

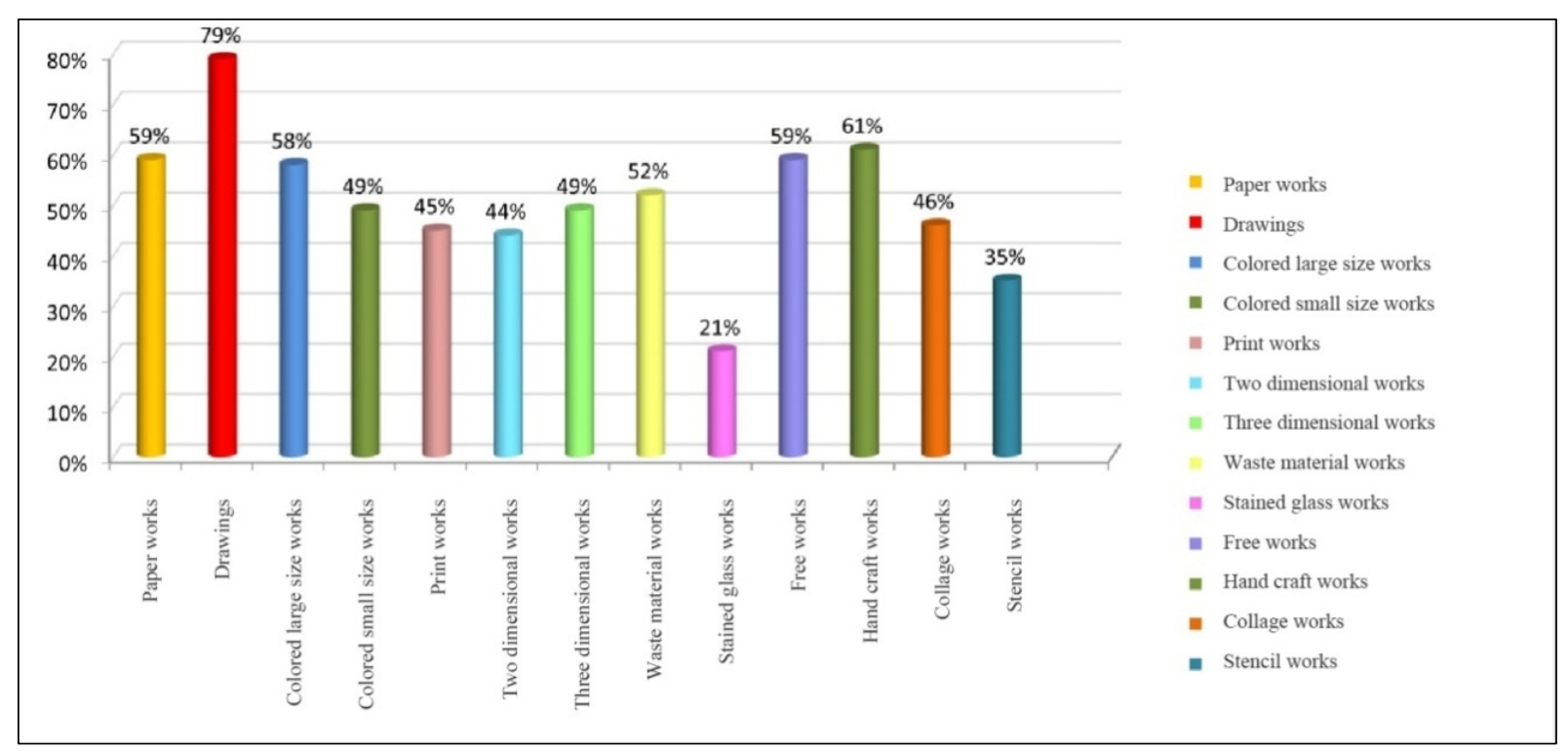

Graph 1. Teachers whose answer is "high" for the influence degree of artistic practices on motor skills development

Analyzing the data in the table, it has been concluded that the most influential method among the types of art works in visual arts fields is the drawings with $79 \%$. The most influential methods after the drawings in sequence are; handcraft works, paper works, free works and colored large size works. It has been concluded that stained glass works with $12 \%$ are considered as a non-influential method. The following methods are stencil works and collage works.

According to the data obtained from the questionnaire, most of the teachers participating in the research have agreed that practicing each topic in the visual arts education program makes a huge contribution to the motor skills development processes of children.

Four percentage column graphs, which show the influence degrees of artistic practices on motor development, have been constructed for each of the answers (high, medium, low, none) given by the teachers to whom the question "At which level do you think these practices used in visual arts field influence the motor skills development?" was asked.

It has been observed from Graph 1 that drawings are thought to be the most influential practice with 79\% among the practices used in the visual arts field. The second most influential practice is the handcraft works with $61 \%$ and paper works and free works come third with $59 \%$. 


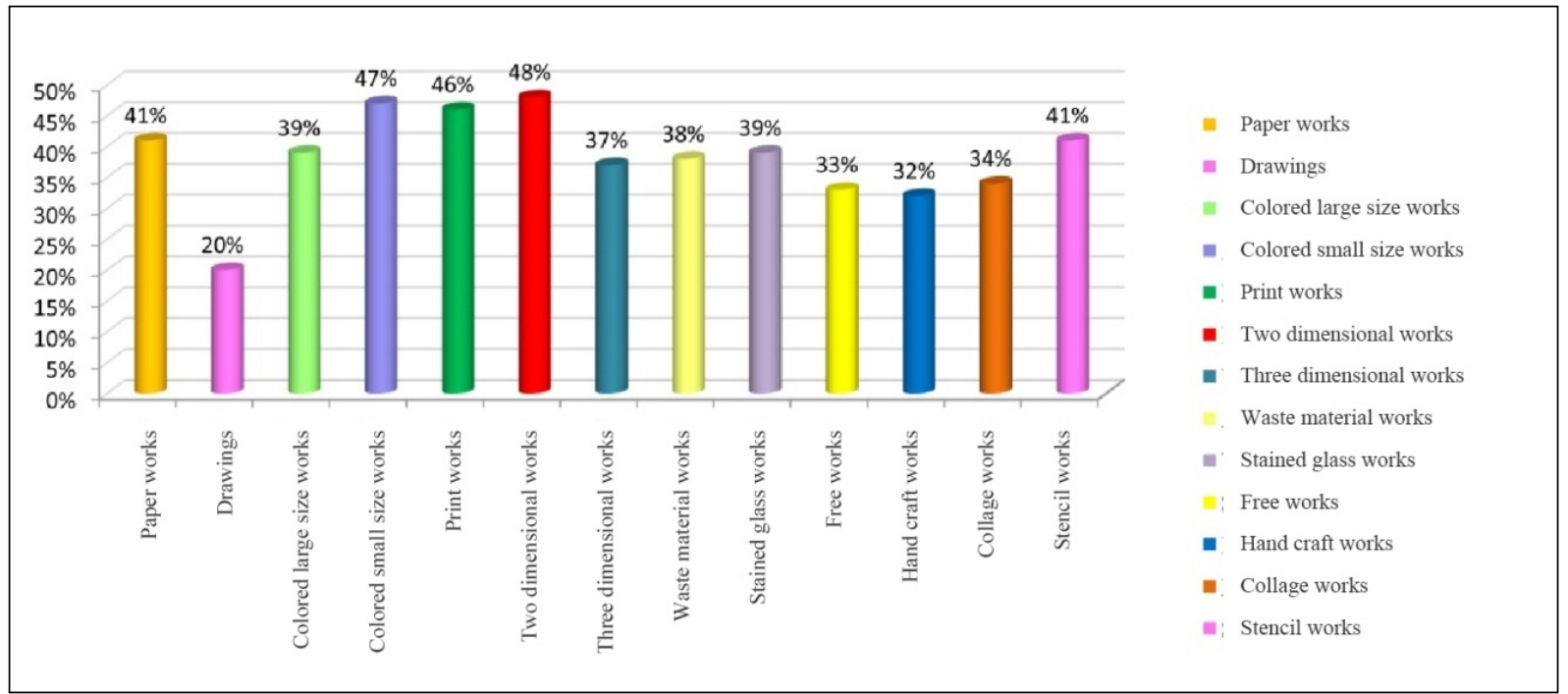

Graph 2. Teachers whose answer is "medium" for the influence degree of artistic practices on motor skills development

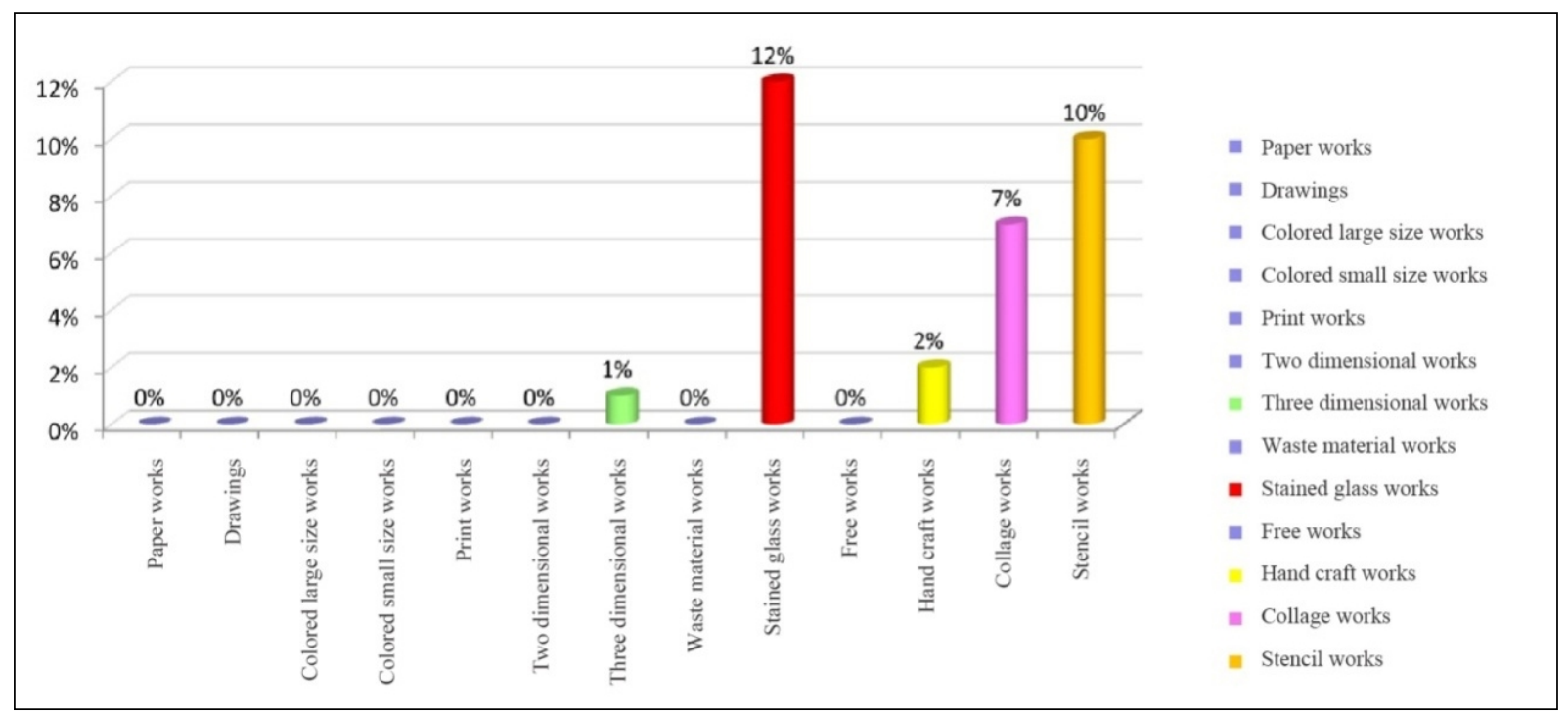

Graph 3. Teachers whose answer is "low" for the influence degree of artistic practices on motor skills development

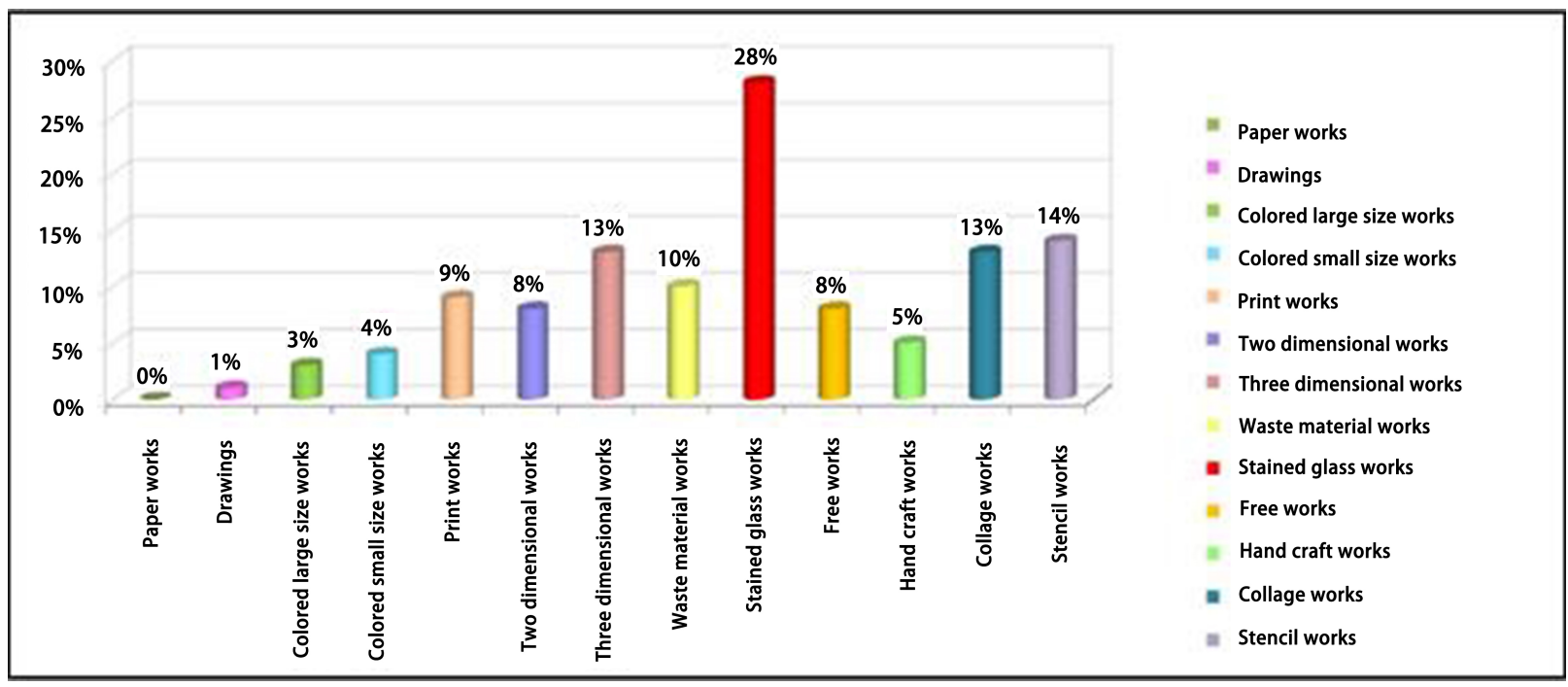

Graph 4. Teachers whose answer is "none" for the influence degree of artistic practices on motor skills development 
It has been observed from Graphic 2 that two dimensional works are thought to be the medium influential practices with $48 \%$ among the practices used in the visual arts field. Colored small size works with $47 \%$ are the second and print works with $46 \%$ are the third on the list.

It has been observed from Graph 3 that stained glass works are thought to be the least influential practices with $28 \%$ among the practices used in the visual arts field. Stencil works with $\% 14$ are the second and three dimensional works and collage works with $13 \%$ are the third on the list.

It has been observed from Graph 4 that stained glass works are thought to have minimal to no influence on motor skills development with $12 \%$ among the practices used in the visual arts field. Other practices with minimal to no influence are stencil works with $10 \%$ and collage works with $7 \%$. It was also observed that during the questionnaires the teachers asked for the definitions of stained glass work, stencil work and collage works did not have a lot of knowledge on the topics.

\section{Conclusion and Suggestions}

In this part of the study, suggestions related to the findings obtained by the results of the findings gathered from the study will be presented.

In this study the findings obtained from the questionnaires, which are related to the influence degree of artistic practices in the visual art education program on motor skills development of mentally retarded children, directed to the special education teachers have been analyzed.

According to the findings obtained from the questionnaires, special education teachers have agreed that practicing each topic from visual art education syllabus makes a huge contribution to children's motor skills development. According to the results of the study, also presented as graphs, drawings are thought to be the most influential method among the practices used in visual arts. It has been concluded that the stain glass works is the non-influential practice. As stain glass Works require special materials and effort, it has not been preferred by the teachers. Teachers have a tendency to prefer the activities which are easy to practice and require easily-found materials. They usually avoid activities which require special research and are expensive to carry out.

During all these activities, mentally retarded children acquire many skills, such as eye contact, hand-eye coordination via using materials, simultaneous two-hand coordination, and learning to help and share, in addition to motor skills acquisition. Most of the special education teachers have agreed that using art education for the education of mentally retarded children has a positive effect on the motor skills development of the children. In order to develop the motor skills level of mentally retarded children, it is suggested that art education programs that contribute to the development of basic motor actions should be practiced.
Field studies and program improvement studies need to be carried out. The importance of basic motor actions on children's developmental process needs to be recognized and a national art program needs to be developed.

Every segment of society should be informed about the importance of art education, which has positive effects on personal and motor skills developments of mentally retarded children. Exclusive programs should be prepared by considering different levels of understanding and developmental processes of each child. As in other schools, visual arts classes in special education institutions should be considered as a separate subject and adequate time needs to be devoted. Special education teachers should be informed about visual art education and workshops should be organized related to the field. Parents should be informed about the positive effects of visual art education on motor development and self-expression levels of children and the effects of an acquisition influences the personality development process on reaching the aimed social scale. Through the activities, which can be performed by inviting artists from various disciplines, alongside the periodical attendance of parents, it should be made possible for students to get socialized and to become informed with the works of these people. With those activities which will provoke the children's interest, it could be possible to make the children more attentive and productive in their artistic practices.

\section{REFERENCES}

[1] Ataman, Ayşegül, etc, (1997), Eğitim Bilimine Giriş, Editor Leyla Küçükahmet, Edition of Gazi Publishing House, 1th Press, 1997;178. Turkish.

[2] Çağlar, Selda, Uluslararası Hukuk ve Türk Hukuk Sisteminde Engellilerin Eğitim Hakkı ve Devlet Yükümlülükleri, Marmara University Institute of Social Sciences, Department of Public Law, (Unpublished Phd Thesis), İstanbul, 2009;70. Turkish.

[3] Eripek, Süleyman, Zihinsel Engelli Çocuklar, Anadolu University Publications, No: 900, Education Faculty Publishings, No: 41, Anadolu University Press, Eskişehir, 1996;134. Turkish

[4] Gel, Yücel - Gökaydın, Nevide - İşpiroğlu, Zehra, (1994), Çağdaş Eğitimde Sanat, Association for Supporting Contemporary Life Publications -9, Demet Publishing House, İstanbul, 1994;42. Turkish.

[5] Gökçe, Fikret, Ankara Üniversitesi 5, Mitat Enç Özel Eğitim Günleri, Confederation of Disabled Publications of Turkey-4, Ankara. 1997; 9. Turkish

[6] Günaydın, Selda, Sanat Eğitimi Kapsamında Resim-İş Eğitiminin Çocuk Esirgeme Kurumlarındaki Çocukların Gelişim Sürecine Katkıları (Unpublished Phd Thesis), Samsun, 2006; 47-48:50:58. Turkish

[7] Kırcaali İftar, Gönül, etc., Zihin Engelliler ve Eğitimleri,ed. Bülbin Sucuoğlu, Kök Publishing House, Ankara, 2009;169. Turkish 
[8] Kulaksızoğlu, Adnan, etc., Farklı Gelișen Cocuklar; Editor Adnan Kulaksızoğlu, Epsilon Publishing House, İstanbul, 2003; 257-258.Turkish.

[9] MEGEP, Çocuk Gelişimi ve Eğitimi, Psikomotor Gelişim, MEGEP, T.C. M.E.B, Ankara. [cited 21 July 2010] p.3, Online available from:

http://megep.meb.gov.tr/mte_program_modul/modul_pdf/141 EO0003.pdf.
[10] Packard, Sandra, Ed. D. Miami University, Art For The Exceptional Child: Job Opportunities For Women, Miami, Florida. 1975. [cited 12 May 2010] Online available from: http://www.eric.ed.gov/

ERICWebPortal/search/detailmini.jsp?_nfpb=true\&_\&ERIC ExtSearch SearchValue 0=ED160495\&ERICExtSearch Sea rchType $0=$ no\&accno $=\bar{E} D 160495$

[11] Paça, Fatih, vd., Özel Eğitim ve Rehabilitasyon Merkezi Zihinsel Engelli Bireyler Destek Eğitim Programı,2008.T.C. Ministry of Education General Directorate of Private Education Institutions, Ankara. [cited 21 July 2010], Online available from:

http://orgm.meb.gov.tr/Destek_egitim_programlari/286_Zihi nsel_prog.pdf

[12] Ün Yıldırım, Necmiye - Yılmaz, İlker,"Mental Retardasyon ve Fiziksel uygunluk", Özveri, T.C. Prime Ministry Administration for Disabled People, Peer-review - Periodicals, Volume I, Point I, Ankara, 2004;86-87. Turkish. 